\title{
Pendampingan Upaya Perbaikan Gizi pada Balita (Studi Kasus di Posyandu Sedap Malam, Dusun Sumbertimo, Desa Arjosari, Kalipare, Malang)
}

Nabigh Abdul Jabbar, Agung Dwi Laksono, Hario Megatsari

Balita atau bayi dengan usia di bawah lima tahun merupakan fase yang sangat penting dalam fase kehidupan manusia. Jika terjadi permasalahan kesehatan pada fase tersebut, maka kemungkinan besar permasalahan kesehatan tersebut akan berdampak pada fase kehidupan selanjutnya. Dalam konteks ini, permasalahan gizi pada balita juga merupakan permasalahan yang krusial untuk ditangani serta perlu mendapatkan prioritas (Pusat Data dan Informasi Kementerian Kesehatan RI., 2015)(Wulansari et al., 2015)(Pramono \& Paramita, 2015).

Secara umum status gizi pada balita dapat dilihat berdasarkan 3 indikator, yaitu (1) berat badan terhadap umur (BB/U); (2) tinggi badan terhadap umur (TB/U); dan (3) berat badan 
terhadap tinggi badan (BB/TB). Permasalahan gizi akan muncul ketika terjadi ketidakseimbangan pada ketiga aspek di atas. Jika terjadi permasalahan pada indikator $\mathrm{BB} / \mathrm{U}$, maka permasalahan yang muncul adalah kurang gizi. Permasalahan stunting atau balita pendek akan muncul ketika indikator TB/U bermasalah. Sedangkan permasalahan pada indikator BB/TB manifestasinya ada dua, yaitu gizi buruk (wasting) dan gizi lebih (overweight)(National Institute of Health Research and Development of Ministry of Health of the Republic of Indonesia, 2019).

Berdasarkan Pemantauan Status Gizi (PSG) 2017 yang dilakukan Kementerian Kesehatan, balita yang mengalami masalah gizi kurang pada 2017 mencapai 17,8\%. Permasalahan gizi lain yang

Kenaikan angka permasalahan terjadi pada stunting, yaitu pada tahun 2016 sebesar $27,6 \%$ dan pada tahun 2017 mengalami kenaikan $29,6 \%$. ada pada balita antara lain adalah angka balita stunting yang mencapai $29,6 \%$, angka balita kurus 9,5\% dan angka balita gemuk mencapai $4,6 \%$. Terdapat perbedaan angka permasalahan gizi di tahun 2016, ada beberapa permasalahan yang angkanya naik ada pula yang turun. Kenaikan angka permasalahan terjadi pada stunting, yaitu pada tahun 2016 sebesar $27,6 \%$ dan pada tahun 2017 mengalami kenaikan 29,6\% (Direktorat Gizi Masyarakat Direktorat Jenderal Kesehatan Masyarakat Kementerian Kesehatan Rl., 2018).

Situasi permasalahan gizi balita di Jawa Timur hampir sama dengan kondisi secara nasional. Profil Kesehatan Indonesia tahun 2016 yang dirilis oleh Kementerian Kesehatan, memberikan gambaran tentang hal tersebut. Persentase balita dengan permasalahan gizi buruk di Jawa Timur sebesar 3,4\% dan gizi kurang 
sebesar 13,9\%. Sedang persentase balita dengan kondisi kerdil/pendek (stunting) di Jawa Timur diklasifikasikan menjadi 2, yaitu sangat pendek sebesar 7,5\% dan pendek 18,6\% (Pusat Data dan Informasi Kementerian Kesehatan RI., 2017).

Upaya perbaikan gizi balita sudah dilakukan dengan berbagai macam cara dan melibatkan banyak pihak selain pemerintah. Program terbaru yang diluncurkan oleh pemerintah adalah program 1000 Hari Pertama Kelahiran (1000 HPK). Program ini sangat berkaitan erat dengan usaha untuk menanggulangi permasalahan gizi yang ada. Pihak lain di luar pemerintah juga memberikan kontribusi dalam hal penanggulangan permasalahan gizi yang ada (Achadi, 2013)(Sumarmi, 2017).

Berdasarkan uraian latar belakang, maka bagian ini disusun untuk mendeskripsikan proses pendampingan upaya perbaikan gizi balita di lokasi penelitian. Upaya pendampingan ini perlu dilakukan agar akselerasi perbaikan status gizi pada balita dapat dengan segera dicapai.

\section{Tiga Tahapan Pelaksanaan}

Riset aksi partisipatif ini didesain secara mixed methods (metode campuran). Desain penelitian terdiri dari tiga tahap secara berurutan, didahului dengan metode kuantitatif, kemudian tahap ke-dua dilakukan secara kualitatif, dan ke-tiga tahap aksi partisipatif berupa pendampingan upaya perbaikan gizi pada keluarga balita.

Tahap pertama dengan metode kuantitatif. Pada tahap ini dilakukan dengan tujuan untuk menilai status gizi balita. Pengumpulan data dilakukan melalui pengukuran antropometri pada seluruh anak balita di Posyandu Sedap Malam, Dusun Sumbertimo, Desa Arjosari, Kecamatan Kalipare, Kabupaten M alang. Pada tahap ini didapatkan balita sejumlah 36 anak.

Pengukuran ini dilakukan untuk menilai status gizi balita di Posyandu tersebut pada tiga kategori, yaitu berat badan per umur 
$(\mathrm{BB} / \mathrm{U})$ untuk menilai balita kekurangan gizi atau tidak, tinggi badan per umur (TB/U) untuk menilai tingkat kependekan balita, dan Indeks Masa Tubuh per umur (IMT/U) untuk menilai tingkat kekurusan balita. Penilaian status gizi balita dalam penelitian ini dibantu dengan alat bantu perangkat lunak AnthroPlus dari WHO (Gibson, 2005)(World Health Organization, 2009). Pengukuran berat badan dengan menggunakan timbangan pegas, pengukuran tinggi badan dengan menggunakan microtoise, dan panjang badan dengan menggunakan length board.

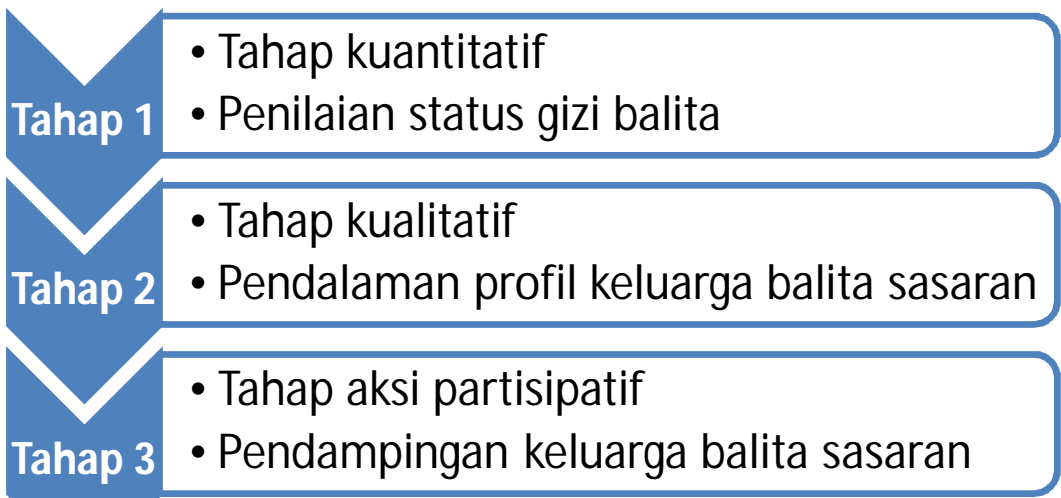

Gambar 7. 1. Tahapan Pelaksanaan

Sumber: Visualisasi peneliti, 2018

Tahap kedua dengan metode kualitatif. Pada tahap ini dilakukan dengan tujuan untuk merumuskan upaya perbaikan gizi pada balita yang mempunyai masalah gizi. Berdasarkan hasil penilaian pada tahap pertama, maka dipilih balita yang mempunyai masalah status gizi pada tiga kategori, yaitu balita gizi kurang dan buruk (underweight), pendek dan sangat pendek (stunting), dan balita kurus dan sangat kurus (wasting). Balita dipilih yang mempunyai minimal dua masalah status gizi, yang akan dilakukan pendalaman untuk mendapatkan profil atau gambaran karakteristik 
keluarga balita (pendidikan orang tua, pola asuh, besaran keluarga, status sosial ekonomi, dan lingkungan)(Laksono, 2015a)(M urlan et al, 2015). Metode pengumpulan data pada tahap dua dilakukan dengan menggunakan metode wawancara mendalam dan pengamatan (Laksono, 2015b)(Kusumawardani et al., 2015). Informasi tentang karakteristik keluarga ini diperlukan untuk merumuskan upaya perbaikan gizi pada balita yang bermasalah gizi. Rumusan upaya perbaikan gizi ini bisa berlaku secara individual atau kelompok, bergantung pada informasi hasil penilaian pada tahap kedua dan sebaran tempat tinggal keluarga balita.

Tahap ke-tiga dilakukan pendampingan pada keluarga balita. Pendampingan disesuaikan dengan status gizi balita dan kondisi keluarga yang didapatkan pada tahap ke-dua dan kesediaan keluarga balita untuk upaya pendampingan.

Penelitian pendampingan upaya perbaikan gizi balita ini merupakan bagian dari Riset Aksi Partisipatif Desa Sehat Berdaya yang dikelola oleh Persakmi Jawa Timur dan YDSF Malang. Pada riset aksi partisipatif tersebut seorang Sarjana Kesehatan Masyarakat ditempatkan sebagai Sahabat Desa di desa terpilih selama satu tahun, pada bulan Mei 2018 hingga April 2019. Sahabat Desa berperan sebagai fasilitator dan pendamping di tingkat desa untuk membuat masyarakat lebih berdaya di bidang kesehatan, pendidikan dan ekonomi (Laksono et al., 2019).

\section{Sekilas tentang Desa Arjosari}

Desa Arjosari merupakan salah satu desa yang terletak di Kecamatan Kalipare, Kabupaten M alang bagian Selatan. Kecamatan Kalipare sendiri terdiri dari 9 Desa, 37 dusun, 60 RW dan 482 RT. Luas dari Desa Arjosari yang terletak di ketinggian 300 mdpl dengan kemiringan $20^{\circ}$ ini seluas 1510,77 $\mathrm{Ha}$. Desa Arjosari memiliki curah hujan yang cukup tinggi, sekitar $1.250 \mathrm{~mm}$ dengan kelembaban $25 \%$ 
dan suhu rata-rata $27^{\circ} \mathrm{C}$. Kondisi ini menyebabkan keadaan di wilayah Desa Arjosari cukup sejuk (Pemerintah Desa Arjosari, 2017).

Mata pencaharian sebagian besar penduduk di bidang pertanian. Kondisi tanah yang berbukit-bukit dan dataran rendah merupakan tempat yang cocok untuk bertani. Sebagian masya-rakat

...rerata tingkat

pendidikan yang

rendah ini juga

menjelaskan bahwa

sebagian besar rumah

tangga di Desa Arjosari

berada pada tingkatan

ekonomi menengah ke

bawah.

lainnya berprofesi sebagai peternak, dan sebagian kecil menjadi guru, PNS, dan profesi lain. Beberapa warga juga didapati menjadi pekerja di luar negeri (TKI dan/atau TKW).

Berdasarkan hasil pengamatan, produk pertanian yang banyak ditemui adalah tebu dan cabai. Hal tersebut merupakan konsekuensi dari tekstur tanah yang keras dan sistem pengairan yang tergolong sulit. Hasil pertanian lain yang bisa ditemui adalah singkong dan jagung, namun pada tahun 2018 para petani lebih memilih untuk menanam tebu, karena biaya operasional yang tergolong murah.

Bidang peternakan juga berkembang di wilayah ini. Masyarakat lebih memilih berternak ayam petelur, yang sebagian besar dilakukan para petani pada musim kemarau. Mereka beralasan menjadi petani telur lebih menjanjikan daripada hasil bercocok tanam di saat kemarau.

Berdasarkan tingkat pendidikan, sebagian besar penduduk hanya mampu menamatkan tingkat pendidikan Sekolah Dasar (Pemerintah Desa Arjosari, 2017). Kondisi rerata tingkat pendidikan yang rendah ini juga menjelaskan bahwa sebagian besar rumah tangga di Desa Arjosari berada pada tingkatan ekonomi menengah 
ke bawah. Kondisi rumah tangga ini yang disinyalir juga berdampak pada kondisi status gizi balita yang kurang baik di Desa Arjosari.

\section{Status Gizi Balita}

Pengukuran antropometri dilakukan pada seluruh balita yang menjadi sasaran di Posyandu Sedap Malam. Didapatkan sekitar 36 balita yang menjadi sasaran. Sejumlah balita tersebut dengan rincian berdasarkan jenis kelamin terdiri dari 19 balita laki-laki dan 17 balita perempuan.

Tabel 7.1. Perbandingan Prevalensi Status Gizi Balita di Posyandu Sedap Malam-Desa Arjosari, Kabupaten M alang, Provinsi Jawa Timur, dan Indonesia

\begin{tabular}{lcccc} 
& \multicolumn{4}{c}{ Prevalensi Status Gizi } \\
\cline { 2 - 5 } Status Gizi & $\begin{array}{c}\text { Posyandu } \\
\text { Sedap Malam } \\
\text { n=36 (\%) }\end{array}$ & $\begin{array}{c}\text { Kab. Malang } \\
(\%)\end{array}$ & $\begin{array}{c}\text { Jawa Timur } \\
(\%)\end{array}$ & $\begin{array}{c}\text { Indonesia4 } \\
(\%)\end{array}$ \\
\hline Underweight & $5(13,89 \%)$ & $17,36 \%$ & $16,80 \%$ & $17,7 \%$ \\
Stunting & $9(25,00 \%)$ & $31,74 \%$ & $32,81 \%$ & $30,8 \%$ \\
Wasting & $4(11,11 \%)$ & $7,47 \%$ & $9,14 \%$ & $10,2 \%$ \\
\hline Sumber: & 1 Data Primer, 2018 & & & \\
& 2-4 Riskesdas 2018 & & &
\end{tabular}

Tabel 7.1 menginformasikan bahwa secara umum status gizi balita di Posyandu Sedap M alam menunjukkan prevalensi yang lebih baik daripada angka provinsi maupun nasional. Pada kategori underweight (gizi buruk dan kurang) dan stunting (kependekan) angka prevalensi terlihat lebih baik, sementara pada kategori wasting (kekurusan) menunjukkan prevalensi yang lebih tinggi.

Berdasarkan informasi dari Tabel 7.2 didapatkan bahwa pada balita dengan kategori umur $\leq 2$ Tahun maupun kategori umur $>2$ 
tahun didominasi oleh kasus stunting. Peringkat masalah ke-dua balita $\leq 2$ Tahun didominasi oleh wasting, sementara posisi ke-dua balita $>2$ tahun didominasi oleh masalah underweight.

Tabel 7.2. Prevalensi Status Gizi Balita Berdasarkan Karakteristik Jenis Kelamin dan Kelompok Umur di Posyandu Sedap Malam 2 Desa Arjosari pada Penimbangan Tanggal 13 Agustus 2018

\begin{tabular}{|c|c|c|c|c|c|c|}
\hline \multirow{3}{*}{ Status Gizi } & \multicolumn{6}{|c|}{ Prevalensi Status Gizi } \\
\hline & \multicolumn{2}{|c|}{ Laki-laki } & \multicolumn{2}{|c|}{ Perempuan } & \multicolumn{2}{|c|}{ Total } \\
\hline & $\begin{array}{c}\leq 2 \text { Tahun } \\
n=9(\%)\end{array}$ & $\begin{array}{l}>2 \text { Tahun } \\
n=10(\%)\end{array}$ & $\begin{array}{c}\leq 2 \text { Tahun } \\
n=8(\%)\end{array}$ & $\begin{array}{l}>2 \text { Tahun } \\
n=9(\%)\end{array}$ & $\begin{array}{l}\leq 2 \text { Tahun } \\
n=17(\%)\end{array}$ & $\begin{array}{l}>2 \text { Tahun } \\
n=19(\%)\end{array}$ \\
\hline Underweight & $0(0,00 \%)$ & $3(30,00 \%)$ & $1(12,50 \%)$ & $1(11,11 \%)$ & $1(5,88 \%)$ & $4(21,05 \%)$ \\
\hline Stunting & $3(33,33 \%)$ & $3(30,00 \%)$ & $1(12,50 \%)$ & $2(22,22 \%)$ & $4(23,53 \%)$ & $5(26,32 \%)$ \\
\hline Wasting & $1(11,11 \%)$ & $0(0,00 \%)$ & $2(25,00 \%)$ & $1(11,11 \%)$ & $3(17,65 \%)$ & $1(5,26 \%)$ \\
\hline
\end{tabular}

Sumber: Data Primer, 2018

Indikator status gizi berdasarkan indeks $\mathrm{BB} / \mathrm{U}$ memberikan indikasi masalah gizi secara umum. Indikator ini tidak memberikan indikasi tentang masalah gizi yang sifatnya kronis ataupun akut, karena berat badan berkorelasi positif dengan umur dan tinggi badan. Indikator BB/U yang rendah dapat disebabkan karena pendek (masalah gizi kronis) atau bisa juga karena sedang menderita diare atau penyakit infeksi lain (masalah gizi akut)(National Institute of Health Research and Development of M inistry of Health of the Republic of Indonesia, 2019).

Indikator status gizi berdasarkan indeks TB/U memberikan indikasi masalah gizi yang sifatnya kronis sebagai akibat dari keadaan yang berlangsung dalam waktu yang lama. Hal ini terjadi misalnya karenafaktor kemiskinan, perilaku hidup tidak sehat, dan asupan makananyang kurang dalam jangka waktu yang lama yang 
dimulai sejak usia bayi sehingga mengakibatkan anak menjadi pendek (stunting) (National Institute of Health Research and Development of Ministry of Health of the Republic of Indonesia, 2019).

Sedang indikator status gizi berdasarkan indeks IMT/U memberikan indikasi masalah gizi yang sifatnya akut sebagai akibat dari peristiwa yang terjadi dalam waktu yang tidak lama (singkat). $M$ isalnya terjadi wabah penyakit dan kekurangan makan (kelaparan) yang mengakibatkan anak menjadi kurus. Indikator BB/TB dan IMT/U dapat digunakan untuk identifikasi kurus dan gemuk. M asalah kurus dan gemuk pada usia dini dapat berakibat pada risiko berbagai penyakit degeneratif pada saat dewasa nantinya. Masalah gizi akut-kronis adalah masalah gizi yang memiliki sifat masalah gizi akut dan kronis. Sebagai contoh adalah anak yang kurus dan pendek (National Institute of Health Research and Development of M inistry of Health of the Republic of Indonesia, 2019).

\section{Profil Keluarga Balita dengan Status Gizi Bermasalah}

Berdasarkan hasil penilaian status gizi balita, maka didapatkan 8 balita dengan minimal 2 status gizi bermasalah. Dari 8 balita, ada 7 keluarga balita yang didampingi. Sementara 1 keluarga balita drop out karena sakit dan pindah domisili dari Desa Arjosari. Pendalaman kasus dilakukan dengan wawancara mendalam dan pengamatan untuk mengetahui profil latar belakang orang tua dan atau keluarga balita, serta pola kesehariannya.

Sahabat Desa dalam proses pendalaman di lapangan dilakukan dengan bantuan kader Posyandu. Hal ini dilakukan untuk pendekatan secara informal kepada ibu dan balita sasaran, serta untuk menggali informasi awal mengenai karakteristik keluarga balita secara umum.

Secara umum berdasarkan hasil wawancara dan observasi, diketahui bahwa tingkat pendapatan orang tua dari balita dengan 
status gizi bermasalah sebagian besar ( 5 dari 7 keluarga) bekerja sebagai buruh dan pekerjaan tidak tetap lainnya. Rata-rata penghasilan mereka Rp 500.000,- per bulan, sehingga dari segi ekonomi dapat dikategorikan berada pada tingkat ekonomi menengah ke bawah.

Pendapatan yang relatif rendah menjadi salah satu penyebab keterbatasan daya beli makanan sehingga berdampak pada status gizi anak. Keterbatasan daya beli makanan seringkali menyebabkan menu makanan balita kurang bervariasi sehingga pemenuhan gizi dirasakan kurang optimal.

Tabel 7.3. Karakteristik Balita Gizi Kurang dan Buruk di Posyandu Sedap M alam 2 Desa Arjosari, Kalipare, Malang

\begin{tabular}{cccccc} 
No & Balita & $\begin{array}{c}\text { Jenis } \\
\text { Kelamin }\end{array}$ & $\begin{array}{c}\text { Umur (dalam } \\
\text { bulan) }\end{array}$ & $\begin{array}{c}\text { Jumlah } \\
\text { Saudara }\end{array}$ & Pengasuh \\
\hline 1 & AD & Laki-laki & 47 & 1 & lbu dan Nenek \\
\hline 2 & AS & Laki-laki & 8 & 2 & Nenek \\
3 & JR & Laki-laki & 35 & 2 & Ayah dan Nenek \\
\hline 4 & DV & Laki-laki & 13 & 3 & Ayah \\
5 & AB & Perempuan & 17 & 1 & Nenek \\
\hline 6 & RF & Laki-laki & 24 & 2 & Nenek \\
7 & CL & Perempuan & 26 & 1 & Ayah dan Nenek \\
\hline
\end{tabular}

Sumber: Data primer, 2018

Kondisi tersebut masih ditambah dengan tingkat Pendidikan orang tua balita yang sebagian besar hanya lulusan Sekolah Dasar (Pemerintah Desa Arjosari, 2017). Dominasi tingkat pendidikan rendah ini menjadi tantangan tersendiri untuk upaya penyelesaian permasalahan gizi, karena semakin rendah tingkat pendidikan orang tua atau pengasuh, maka pengetahuan mereka tentang gizi balita 
juga seringkali rendah. Hal ini pada akhirnya secara tidak langsung berdampak pada status gizi balita.

Berdasarkan Tabel 7.3 dapat diketahui bahwa balita yang mengalami masalah gizi kurang dan buruk (underweight) seringkali diasuh oleh ayah dan/atau neneknya. Hasil wawancara mendalam menemukan bahwa ayah atau nenek kurang memahami permasalahan gizi dan pola makan sehat pada anak. Seringkali variasi makanan yang diberikan kurang.

Selanjutnya kondisi balita dengan status gizi bermasalah dinarasikan sebagai sebuah studi kasus. Narasi disertai dengan keterangan tentang profil keluarga balita.

\section{Balita AD}

Balita $A D$ adalah anak pertama dari orang tua yang sudah berhenti dan pulang dari luar negeri sebagai Tenaga Kerja Indonesia (TKI), dan saat ini bekerja sebagai buruh tani. Balita yang berusia 47 bulan ini memiliki berat badan $11 \mathrm{~kg}$ dan tinggi badan $91 \mathrm{~cm}$. Pada kondisi tersebut balita AD masuk pada kategori gizi kurang menurut pengukuran $\mathrm{BB} / \mathrm{U}$, dan masuk pada kategori kurus untuk pengukuran IMT/U.

Walau orang tua balita $A D$ memiliki rumah sendiri namun setiap harinya $A D$ menghabiskan waktu lebih banyak dengan neneknya. Karena pekerjaan ayah dan ibu AD hanya buruh tani. Untuk makan, balita AD hanya mendapatkan makanan sekedar saja dari neneknya. Neneklah yang mengasuh penuh balita AD apabila ditinggal orang tuanya ke kebun.

Dalam kesehariannya, nenek tinggal di rumah bersama adik dari ibu balita $A D$ (bibi), yang membantu untuk pekerjaan rumah. Bibi dari balita $A D$ belum menikah, kesehariannya juga pergi berkebun untuk membantu neneknya mendapatkan penghasilan dan keperluan makan sehari-hari. 
Selain miskin, tingkat pendidikan orang tua balita $A D$ juga rendah. Berdasarkan hasil wawancara mendalam juga diketahui orang tua balita AD memiliki pengetahuan masalah gizi yang kurang. Karena hanya memiliki ijazah Sekolah Dasar, kedua orang tua balita AD terpaksa menjadi buruh tani dengan penghasilan rendah dan tidak tetap.

Kondisi keseharian balita $A D$ ini memperlihatkan bahwa balita $A D$ kurang mendapat perhatian dari orang tuanya. Berdasarkan pengamatan, seringkali balita AD diberi makanan ringan (snack) pabrikan dan minuman berperisa, karena jika tidak diberi balita akan berontak dan menangis.

\section{Balita AS}

Hasil pengukuran antropometri menunjukkan bahwa dengan berat badan $14 \mathrm{~kg}$ dan tinggi badan 61 centimeter, pada kategori $\mathrm{BB} / \mathrm{U}$ balita AS termasuk gizi kurang. Dengan kondisi tersebut balita berumur 8 bulan tersebut juga masuk kedalam kategori pendek. Sedang pada kategori pengukuran IMT/U balita AS dikategorikan dalam kurus.

Balita AS merupakan dua bersaudara, kakaknya saat ini sedang menempuh pendidikan SMP. Balita AS tinggal serumah dengan nenek dan kakeknya, sehingga satu rumah dihuni oleh enam orang anggota keluarga. Rumah yang dihuni balita AS sangat sederhana. Rumah yang mempunyai dua kamar ini memiliki ruang tamu dan dapur yang menjadi satu. M eski sederhana, rumah yang ditinggali balita AS sudah berlantai plester. Selain itu keluarga balita AS juga memiliki kandang hewan, yang isinya merupakan hewan ternak titipan tetangga.

Ayah balita AS yang lulusan SD bekerja seadanya sebagai seorang buruh. Terkadang menjadi buruh di ladang, dan sesekali menjadi buruh bangunan apabila ada tetangga yang sedang merenovasi rumah. Sementara itu ibu balita AS membantu nenek 
dan kakek untuk mencarikan pakan bagi hewan ternak yang dirawat oleh keluarga tersebut.

Tingkat pendidikan yang rendah dan tingkat ekonomi yang pas-pasan dirasakan cukup berat, untuk menghidupi kebutuhan sehari-hari, untuk lima orang anggota keluarga yang hanya mengandalkan penghasilan ayah balita AS.

Berdasarkan pengamatan di lapangan, dalam keseharian dan kebiasaan keluarga ini sering hanya menanak nasi saja. Sedang untuk tambahan lauk-pauk mereka harus menunggu ibu atau nenek balita AS membawakan makanan seadanya dari kebun. Pada akhirnya situasi ini bisa dipahami saat ibunya menyatakan bahwa balita AS sulit makan.

\section{Balita JR}

Balita JR adalah anak bungsu dari dua bersaudara. Berdasarkan pengukuran IMT/U balita JR termasuk dalam kategori kurus. Balita berumur 35 bulan ini tergolong normal pada pengukuran TB/U, karena JR memiliki berat badan $8 \mathrm{~kg}$ dan tinggi badan $90 \mathrm{~cm}$. Sedang untuk pengukuran BB/U balita JR tergolong dalam gizi kurang.

Balita JR ditinggal ibunya semenjak umur dua bulan. Ibu balita JR bekerja di luar negeri menjadi Tenaga Kerja Wanita (TKW) di Korea. Ibu balita JR berperan sebagai tulang punggung keluarga ini. Sementara itu ayah balita JR yang lulusan SMP tidak bekerja, hanya menunggu kiriman uang dari istrinya.

Keluarga balita JR tinggal di rumah sederhana bersama kakek dan neneknya. Praktis rumah kecil sederhana tersebut dihuni oleh lima orang anggota keluarga.

Keseharian balita JR kurang mendapat perhatian. Peran ibu digantikan oleh nenek, termasuk untuk ketersediaan makanan. Menurut pengakuan neneknya, balita JR dimanjakan tanpa mempertimbangkan baik-buruk menu jenis makanan yang diminta. 
Baik untuk makanan utama maupun makanan kudapan, yang sebagian besar jenis makanan ringan (Ch**i). Dengan demikian, tidak hanya kurang perhatian, balita JR juga terbiasa mendapatkan makanan ringan berlimpah MSG daripada makanan pendamping, atau pengganti ASI.

\section{Balita DV}

Balita DV adalah anak ke-tiga dari tiga bersaudara. Berdasarkan hasil pengukuran antropometri, balita berumur 13

....kebutuhan yang

tidak esensial

semacam gawai

(handphone),

dimainkan oleh anak

dalam keseharian,

tetapi ternyata

asupan gizinya tidak

terpenuhi. bulan ini memiliki berat badan 7,1 $\mathrm{kg}$ dan tinggi badan $77 \mathrm{~cm}$, yang artinya DV memiliki status gizi kurang untuk kategori BB/U. Sedang pada kategori IMT/U balita DV termasuk kurus.

Ayah dari balita DV adalah seorang peternak ayam petelur, sementara ibunya menjadi seorang TKW di Taiwan. Balita DV masih di dalam kandungan ibunya sampai beberapa waktu selama ibunya bekerja di luar negeri.

Setelah usia kandungan berusia sekitar lima bulan, kemudian ibu DV kembali ke Indonesia sambil menunggu DV lahir.

Saat ini balita DV tinggal berlima dengan dua kakak, ayah dan neneknya. Dalam keseharian, ayah balita DV menyerahkan segala urusan domestik, termasuk pengasuhan dan asupan makanan, pada nenek balita DV.

Berdasarkan pengamatan, meski secara perekonomian keluarga balita DV termasuk bagus, tetapi pengetahuan tentang pola pengasuhan dan gizi balita dirasakan kurang memadai. Kondisi 
ini disinyalir berdampak pada status gizi balita DV yang masuk dalam kategori gizi kurang.

Dilema ini memang sering terjadi pada keluarga balita yang ibunya menjadi TKW ke luar negeri. Karena perekonomian yang baik, kebutuhan yang tidak esensial semacam gawai (handphone), dimainkan oleh anak dalam keseharian, tetapi ternyata asupan gizinya tidak terpenuhi.

\section{Balita AB}

Balita $A B$ adalah anak pertama dari dua bersaudara. Keluarga balita berumur 17 bulan ini tinggal dalam satu rumah bersama neneknya. Total ada lima anggota keluarga dalam satu rumah. Berdasarkan pengukuran, balita $A B$ memiliki berat badan 9 $\mathrm{kg}$ dan tinggi badan $87 \mathrm{~cm}$. Catatan pengukuran ini memasukkan balita $A B$ dalam kategori gizi kurang dan kurus.

Orang tua balita $A B$ bekerja sebagai buruh tidak tetap. Jika sedang tidak ada yang membutuhkan tenaga mereka, orang tua balita $A B$ berkebun di tanah milik mereka yang tidak terlalu luas, untuk sekedar menanam singkong atau cabai. Ayah balita $A B$ merupakan tamatan SD, sedang ibunya sempat menamatkan bangku SM P.

Balita AB dalam keseharian lebih banyak dihabiskan bersama dengan neneknya. Praktis hanya ada nenek di rumah jika orangtua balita $A B$ bekerja. Sehingga pengasuhan balita $A B$ lebih diperankan oleh neneknya, termasuk pola asupan makanan.

Berdasarkan pengamatan, keluarga balita $A B$ masuk dalam kategori tidak mampu. Karena alasan ekonomi inilah yang menyebabkan balita $A B$ jarang mendapatkan makanan yang cukup. Makanan yang paling sering tersedia adalah singkong dan nasi empok (jagung), dan sayangnya balita $A B$ tidak begitu menyukai jenis makanan tersebut. 


\section{Balita RF}

Balita RF adalah anak bungsu dari dua bersaudara. Keluarga balita berumur 24 bulan ini tinggal di rumah sederhana, namun

relatif lebih baik daripada balita

...meskipun di rumah tersebut ada nenek balita RF. Menjadi ayah sekaligus ibu untuk anak-anak memang tidak mudah, namun begitulah kondisi yang harus dijalani.

yang bermasalah status gizi lainnya. Rumah balita RF sudah berlantai porselen.

Ibu dari RF adalah mantan TKW. Saat ini ibunya sudah tidak tinggal bersama dengan RF, karena telah bercerai dengan ayahnya. Kondisi ini mengharuskan balita RF dan saudaranya hanya tinggal bersama nenek dan ayahnya saja.

Berdasarkan pengamatan, keluarga RF tergolong cukup mampu. Ayahnya berprofesi sebagai peternak ayam. Meski demikian tidak menjamin kebu-tuhan gizi balita RF tercukupi dengan baik. Balita RF memiliki berat badan 9,8 kg dan tinggi badan $82 \mathrm{~cm}$. Berdasarkan kategori BB/U dan IMT/U menunjukkan bahwa balita RF termasuk dalam kategori gizi kurang, dan memiliki tubuh yang sangat kurus (wasting).

Ayah balita RF berperan sebagai bapak sekaligus ibu untuk anak-anaknya (single parent). Situasi ini membawa konsekuensi beban hidup ayah balita RF menjadi lebih berat, meskipun di rumah tersebut ada nenek balita RF. Menjadi ayah sekaligus ibu untuk anak-anak memang tidak mudah, namun begitulah kondisi yang harus dijalani.

Dalam keseharian, balita RF dan kakaknya hanya mendapatkan perhatian dari sang nenek. Pengetahuan nenek tentang gizi makanan yang kurang membuat balita RF jarang 
mengkonsumsi makanan yang baik untuk tumbuh kembang. Sedang ayah balita RF yang lulusan SM P juga kurang memperhatikan jenis asupan makanan untuk anaknya. Ayah balita RF hanya berfokus pada peternakan ayam yang digeluti. Nenek balita RF menyediakan makanan juga seadanya, sekedar ada nasi dan lauk sudah bisa dikatakan cukup untuk makan.

\section{Balita CL}

Balita CL adalah sulung dari dua bersaudara. Pada awalnya kedua orang tua CL bekerja di luar negeri, namun saat ini sang ayah memutuskan untuk tidak kembali ke Malaysia. Sedang ibu balita yang berusia 26 bulan tersebut masih menjadi TKW sampai dengan saat ini. Keluarga balita CL tinggal bertujuh dalam satu rumah, karena ada keluarga ibunya yang turut bergabung dalam rumah tersebut.

Jika dilihat berdasarkan status gizi, balita CL setidaknya memiliki tiga permasalahan. Balita $\mathrm{CL}$ memiliki berat badan $10 \mathrm{~kg}$ dan tinggi badan $74 \mathrm{~cm}$. Berdasarkan kategori BB/U, TB/U dan IMT/U, balita $\mathrm{CL}$ termasuk pada kategori gizi kurang, pendek dan kurus.

Ditinggal ibunya menjadi TKW, menjadi beban untuk ayah balita CL dan keluarga lainnya untuk menggantikan peran ibu. Ayahnya yang lulusan SMA kurang paham terhadap asupan makanan yang harus dikonsumsi oleh balita CL. Ayahnya memberi makanan apa saja yang diinginkan balita $\mathrm{CL}$, bukan apa yang seharusnya menjadi asupan anak balita.

Keluarga balita CL hanya mengandalkan uang hasil kerja sang ibu untuk memenuhi kebutuhan sehari-hari. Kondisi ini memaksa keluarga balita CL menjalani hidup secara sangat sederhana, termasuk soal asupan makanan. 


\section{Pendampingan Keluarga Balita}

Metode pendampingan dipilih berdasarkan hasil diskusi dan kesepakatan beberapa stake holder terkait, baik dari Persakmi, Puskesmas dan Bidan desa. Tujuan pendampingan ini sejalan dengan program yang ada dan dilaksanakan oleh pihak Puskesmas untuk menurunkan angka balita dan anak yang mengalami gizi kurang dan gizi buruk. Pendampingan ini juga merupakan salah satu intervensi preventif bagi balita dan anak untuk terhindar dari gizi kurang dan buruk.

Pilihan untuk masalah gizi kurang dan buruk (underweight) dibanding masalah kependekan (stunting) karena pertimbangan waktu. Masalah stunting tidak memungkinkan diselesaikan dengan

Pendampingan dilakukan dengan cara kunjungan dari rumah ke rumah. Terobosan ini dilakukan oleh

Sahabat Desa agar lebih fokus dalam penurunan angka balita gizi kurang bahkan buruk.

intervensi dalam waktu hanya beberapa bulan. Dengan pertimbangan waktu tersebut, maka dipilihlah masalah underweight sebagai bahan evaluasi intervensi pendampingan (Gibson, 2005)(World Bank, 2010)(Aryastami et al., 2017) (Moradi et al., 2019) (Nyati, Pettifor, \& Norris, 2019).

Bentuk dari pendampingan ini adalah dengan melakukan edukasi secara langsung kepada keluarga yang memiliki balita gizi kurang dan buruk. Secara teknis, edukasi secara langsung ini mempertemukan Sahabat Desa dengan pihak keluarga, sehingga Sahabat Desa dapat melakukan persuasi pada pihak keluarga untuk bersedia mengikuti saran dari petugas kesehatan.

Upaya pendampingan gizi pada keluarga atau pengasuh dari balita dan anak gizi kurang dilakukan seminggu sekali selama tiga 
bulan. Sekali pertemuan pendampingan berlangsung selama kurang lebih satu sampai dua jam. Pendampingan dilakukan dengan cara mendatangi rumah tempat tinggal keluarga ibu balita dan anak sasaran.

Program pendampingan ditujukan untuk memberikan perawatan kepada balita dan anak gizi kurang. Pendampingan dilakukan dengan cara kunjungan dari rumah ke rumah. Terobosan ini dilakukan oleh Sahabat Desa agar lebih fokus dalam penurunan angka balita gizi kurang bahkan buruk. Proses pendampingan gizi dilakukan untuk memudahkan interaksi dengan ibu atau keluarga balita dan balita gizi kurang atau buruk. Pendampingan gizi memungkinkan terjadinya interaksi timbal balik antara Sahabat Desa dan sasaran (ibu atau keluarga balita dan anak).

Pada setiap kunjungan pendampingan, terhadap keluarga atau ibu, diberikan leaflet sebagai alat bantu dalam memahami materi yang disampaikan. Selain itu, dilakukan juga pendekatan kepada balita untuk mengetahui kondisi dan perkembangan balita tersebut.

\section{Leaflet dipilih dengan}

Tahapan dalam kegiatan pendampingan dimulai dengan komunikasi informal dengan ibu atau keluarga balita untuk mendapatkan informasi mengenai karakteristik keluarga...

mempertimbangkan efisiensi dan efektifitasnya dalam membantu menyampaikan materi pendampingan. Leaflet didesain semena-rik mungkin agar ibu atau keluarga balita tertarik untuk membaca. Tema yang disampaikan disesu-aikan dengan kondisi di lapang (sesuai dengan masukan dari ibu atau keluarga balita) serta kondisi anak yang mengalami permasalahan gizi. 
Tahapan dalam kegiatan pendampingan dimulai dengan komunikasi informal dengan ibu atau keluarga balita untuk mendapatkan informasi mengenai karakteristik keluarga, pengetahuan gizi, serta pola asuh. Setelah itu baru dilakukan pemberian materi, baik melalui leaflet maupun komunikasi langsung. Pada tahap akhir, pendamping terlibat secara langsung dengan kegiatan yang sedang dilakukan oleh balita, seperti bermain, memberi makan, atau bahkan membantu ibu dalam memberikan makanan tambahan pada balita.

Materi pendampingan didasarkan pada pengamatan terhadap pengasuh (ibu/nenek dan ayah) dan anak. Berdasarkan hasil pengamatan tersebut maka dipilih materi pendampingan yang paling sesuai, sebagaimana disajikan pada tabel 7.4 berikut.

Tabel 7.4. Waktu Kunjungan dan Materi Pendampingan

\begin{tabular}{lll}
\hline $\begin{array}{l}\text { Pendam- } \\
\text { pingan ke }\end{array}$ & \multicolumn{1}{c}{ Waktu } & \multicolumn{1}{c}{ Materi } \\
\hline I-III & September 2018 & Menu makanan seimbang pada bayi dan balita \\
IV-VI & Oktober 2018 & Makanan selingan yang baik untuk balita \\
VII-IX & Oktober 2018 & Penyebab dan tips menghadapi susah makan pada balita \\
X-XII & November 2018 & Pengasuhan anak \\
\hline
\end{tabular}

Sumber: Data primer, 2018

\section{Pendampingan I-III}

Tema pendampingan pertama adalah menu makanan seimbang pada bayi dan balita. Pada tahap ini Sahabat Desa sebagai pendamping tidak langsung memberikan penyuluhan. Sahabat Desa lebih memilih untuk mengenal dan bertanya mengenai keluarga serta pendidikan dan pola asuh yang selama ini diterapkan oleh keluarga baik ibu, ayah ataupun nenek. Pertimbangan untuk tidak secara langsung menyampaikan materi tentang masalah gizi, untuk 
menghindari responn sasaran yang kurang berkenan. Pendamping memilih untuk lebih mengakrabkan dengan keluarga balita atau pengasuh.

Pada pertemuan selanjutnya Sahabat Desa memberikan penjelasan ringan mengenai permasalahan gizi yang bisa mengganggu, dan sekedar menanyakan bagaimana kondisi balita tersebut. Pada pertemuan lanjutan ini rasa antusias keluarga mulai muncul dan banyak sasaran yang menerima dengan positif kunjungan yang dilakukan Sahabat Desa.

Pertemuan selanjutnya Sahabat Desa mulai menggunakan alat bantu berupa leaflet yang dilengkapi dengan gambar-gambar aneka menu untuk memudahkan klien memahami materi yang disampaikan. Pada tahap ini penjelasan yang diberikan mengenai konsep pemberian makan, porsi makan, frekuensi makan dan menu seimbang pada balita, serta pedoman umum gizi seimbang untuk keluarga.

Pada pendampingan pertama juga dilakukan pengamatan terhadap balita sasaran mengenai kebiasaan makan sehari-hari. Berdasarkan pengamatan ditemukan kebiasaan balita yang terbiasa mengkonsumsi jajanan sembarangan, terutama jajanan yang mengandung bahan tambahan.

\section{Pendampingan IV-VI}

Materi pada pendampingan ke-empat didasarkan pada pengamatan minggu pertama, yaitu jenis makanan selingan yang baik untuk balita. Berdasarkan pengamatan, mereka terbiasa jajan sembarangan dan ibu kurang memperhatikan bahaya dari kebiasaan tersebut. Jajanan yang mereka konsumsi pada umumnya berupa jajanan rendah kalori serta mengandung bahan tambahan yang berbahaya. Hal ini terlihat dari warna makanan yang mencolok, seperti agar-agar dan ch**i non-food grade dan kurang terjamin kebersihannya. 
Pendampingan pada tahap ini diinformasikan mengenai makanan selingan yang sehat bagi anak. Ibu diberi pengetahuan mengenai bahaya mengkonsumsi jajanan yang tidak sehat sekaligus mengajari mereka untuk membuat makanan selingan yang sehat, padat gizi, dan dengan harga yang terjangkau. Pada tahap kunjungan kali ini ditemukan permasalahan lainnya, yaitu kebiasaan balita yang susah makan.

Informasi menarik lain yang disampaikan oleh Sahabat Desa selaku pendamping adalah pengolahan makanan tambahan yang berasal dari sayuran atau buah yang mudah didapat di Desa Arjosari. Dengan pembekalan materi ini diharapkan tidak ada alasan lagi untuk tidak memberikan makanan tambahan tersebut sebagai penunjang makanan untuk balita. Beberapa contoh makanan olahan tersebut adalah yang terbuat dari daun kelor, jagung, kacangkacangan, termasuk beberapa makanan yang berserat tinggi lainnya.

\section{Pendampingan VII-IX}

Pendampingan pada minggu ketujuh informasi yang diberikan berkembang pada materi mengenai tips-tips menghadapi

...dibahas pula penyebab balita susah makan dan tindakan keliru yang sering dilakukan orang tua dalam menghadapi kebiasaan susah makan pada balita. balita yang susah makan. Materi dipilih berdasarkan pengamatan yang dilakukan pada pendampingan ke-empat. Selain itu, dibahas pula penyebab balita susah makan dan tindakan keliru yang sering dilakukan orang tua dalam menghadapi kebiasaan susah makan pada balita.

Kebiasaan susah makan cenderung dibiarkan oleh keluarga atau ibu balita. Mereka beralasan bahwa telah kehabisan akal 
untuk membujuk balita agar mau makan. Apabila kebiasaan ini dibiarkan terus-menerus maka akan berdampak pada semakin memburuknya status gizi balita karena pemenuhan asupan gizi yang tidak mencukupi. Menyikapi hal ini, Sahabat Desa memberikan pengertian dan keyakinan kepada ibu sehingga mereka mau berusaha lebih keras dan lebih sabar dalam menghadapi balita yang mengalami kesulitan makan.

Tidak hanya pada pengasuh atau keluarga balita, Sahabat Desa selaku pendamping juga merayu balita untuk lebih sering makan, sehingga bukan hanya keluarga yang berusaha, anak pun juga termotivasi. Cara lain adalah dengan memberi anak sebuah reward jika telah makan dengan lahap. Reward ini juga bisa menjadi solusi untuk meningkatkan keinginan anak untuk makan, dengan catatan hadiah disini berupa makanan penunjang untuk gizi ataupun hal yang positif, bukan malah membelikan hadiah makanan ringan seperti sebelumnya.

\section{Pendampingan X-XII}

Pada pendampingan ke-sepuluh, Sahabat Desa memberikan reward pada pengasuh balita berupa booklet yang berisi kumpulan resep makanan. Reward diberikan agar ibu termotivasi untuk moncoba variasi menu yang bergizi pada balita. Resep tersebut merupakan resep yang mudah dipraktekkan dan sekaligus diberikan informasi mengenai kandungan gizinya.

Selain pemberian reward, Sahabat Desa juga tetap memberikan materi berupa pengasuhan anak yang lebih ditekankan kepada sasaran keluarga yang mengasuh anak dan pemahaman yang lebih kepada nenek karena keterbatasan usia. Materi ini diberikan agar keluarga dan ibu balita mengerti tentang konsep pengasuhan anak. 


\section{Respon Keluarga Terhadap Pendampingan}

Respon keluarga dalam memperhatikan materi pendampingan mengalami peningkatan. Pada minggu pertama, terdapat dua informan yang menolak kedatangan Sahabat Desa karena tidak bersedia diberikan pendampingan dengan alasan keterbatasan waktu dan akan pergi ke kebun.

"Iya mas, mbenjeng mawon, tasih bade bidal ten tegil, wayah e tandur mas, sepurane. Arek e yo sek dolen. Wis ya mas tak tinggal ning omah ora enek uwong."

(Iya mas, besok saja, masih mau berangkat ke kebun, waktunya menanam makanan mas, mohon maaf. Anaknya juga masih bermain. Sudah ya mas tak tinggal, di rumah tidak ada orang)

(ibu balita AB).

"Ndisik ka ewes tau mas enek bu bidan mbek mas Bayu (perawat) ngeterne biscuit, tapi anakku ra gelem. Anakku ancen mangan e angel mas, ora usah dikeki maneh biscuit e yo gapopo. Ndek winginani dikekne tanggane mas."

(Dulu sudah pernah ada bu bidan dan mas bayu perawat yang mengantarkan biskuit, tapi anak saya tidak mau. Anak saya makannya susah mas, tidak usah diberi biskuit lagi juga tidak apa-apa. Biskuit yang kemarin diberikan tetangga mas) (ibu balita CL)

Penolakan pendampingan hanya terjadi pada minggu pertama, sedangkan pada minggu selanjutnya semua informan bersedia diberikan materi pendampingan. Pada minggu pertama, respon keluarga cukup rendah dan cenderung pasif hal ini mungkin karena Sahabat Desa hanya menanyakan mengenai keluarga dan balita serta melihat kondisi lingkungan rumah. Kurangnya respon dari keluarga dilihat dari kekurangfokusan mereka dalam menerima materi pendampingan. Kondisi ini juga ditandai dengan tidak adanya 
pertanyaan yang diajukan kepada Sahabat Desa Reaksi yang ditunjukkan sasaran merupakan suatu hal yang lumrah pada tahap awal.

Pada minggu ke-empat dan ke-tujuh terjadi peningkatan respon masyarakat sasaran terhadap materi pendampingan. Hal ini terlihat dari munculnya pertanyaan yang diajukan kepada Sahabat Desa sewaktu kegiatan pendampingan berlangsung. Salah satunya adalah sebagai berikut;

“Pak, kalo anak makannya sering tapi tetep minta jajan apa dibolehkan? Kadang makannya tetap tiga kali pak, tapi mesti minta beli susu sama roti-roti ngoten. Pripun nggeh pak?" (Pak, kalau anak makannya sering tapi tetep minta jajan apa diperbolehkan? Kadang makannya tetap tiga kali pak, tapi mesti minta beli susu sama roti-roti begitu. Bagaimana ya pak?)

(Ibu Balita RA)

Serta pihak keluarga dengan sendirinya menanyakan solusi jika anak masih tidak mau makan (rewel). Tidak hanya itu, keluarga juga menceritakan kegiatan anak walau Sahabat Desa tidak meminta untuk keluarga menceritakan mengenai keseharian anak selama proses pendampingan.

Berdasarkan hasil evaluasi tersebut maka dapat dikatakan proses intervensi berupa pendampingan pada pengasuh atau keluarga balita berjalan cukup baik. Ada perubahan pengetahuan dan kemauan pengasuh untuk berubah ke arah lebih baik.

\section{Perkembangan Status Gizi Balita}

Berat badan balita sebelum dan sesudah pendampingan dipantau sebagai tolak ukur keberhasilan kegiatan. Sebagian besar berat badan balita meningkat setelah dilakukan pendampingan. Sebanyak 6 balita mengalami peningkatan berat badan, sementara 1 orang berat badannya tetap (Tabel 7.5). 
Tabel 7.5. Berat Badan Balita Gizi Buruk Sebelum Dan Sesudah Pendampingan

\begin{tabular}{|c|c|c|c|c|c|c|}
\hline \multirow[b]{2}{*}{ No } & \multirow[b]{2}{*}{ Balita } & \multirow{2}{*}{$\begin{array}{l}\text { Jenis } \\
\text { Kelamin }\end{array}$} & \multirow{2}{*}{$\begin{array}{l}\text { Usia } \\
\text { (bulan) }\end{array}$} & \multicolumn{2}{|c|}{ Berat Badan (kg) } & \multirow{2}{*}{$\begin{array}{c}\% \\
\text { Kena- } \\
\text { ikan } \\
\text { BB }\end{array}$} \\
\hline & & & & $\begin{array}{c}\text { Sebelum } \\
\text { Pendampingan }\end{array}$ & $\begin{array}{c}\text { Setelah } \\
\text { Pendampingan }\end{array}$ & \\
\hline 1 & $A D$ & Laki-laki & 47 & 11 & 11,9 & 8,2 \\
\hline 2 & AS & Laki-laki & 8 & 14 & 14,4 & 2,9 \\
\hline 3 & $J R$ & Laki-laki & 35 & 8 & 8,4 & 5 \\
\hline 4 & DV & Laki-laki & 13 & 7,1 & 7,6 & 7 \\
\hline 5 & $A B$ & Perempuan & 17 & 9 & 9,8 & 8,9 \\
\hline 6 & $\mathrm{RF}$ & Laki-laki & 24 & 9,3 & 9,3 & 0 \\
\hline 7 & $\mathrm{CL}$ & Perempuan & 26 & 5,6 & 6 & 7,1 \\
\hline & & Rata-rata & & 9,14 & 9,62 & 5,6 \\
\hline
\end{tabular}

Sumber: Data primer, 2018

Berat badan rata-rata balita mengalami peningkatan sebesar $5,6 \%$. Status gizi balita sebelum dan setelah pendampingan diukur, dan kemudian dibandingkan dengan standar baku WHONHCS menggunakan indeks BB/U (World Health Organization, 2009). Pengklasifikasian status gizi balita disajikan pada Tabel 7.6.

Tabel 7.6. Klasifikasi Status Gizi Balita Kategori BB/U Sebelum dan Setelah Pendampingan

\begin{tabular}{llcccc}
\hline \multirow{2}{*}{$\begin{array}{c}\text { Klasifikasi Status } \\
\text { Gizi }\end{array}$} & Baku WHO-NHCS & \multicolumn{2}{c}{$\begin{array}{c}\text { Sebelum } \\
\text { Pendampingan }\end{array}$} & \multicolumn{2}{c}{$\begin{array}{c}\text { Setelah } \\
\text { Pendampingan }\end{array}$} \\
\cline { 3 - 6 } & & $n$ & $\%$ & $n$ & $\%$ \\
\hline Gizi lebih & $>2$ SD & - & - & - & - \\
Gizi baik & -2 SD s/d + 2 SD & - & - & 5 & 72 \\
Gizi kurang/buruk & -3 SD s/d - 2 SD & 7 & 100 & 2 & 28 \\
\hline & Total & 7 & 100 & 7 & 100 \\
\hline
\end{tabular}

Sumber: Data primer, 2018 
Berdasarkan informasi pada Tabel 7.6 maka terlihat ada 5 balita yang sebelumnya memiliki masalah gizi kurang/buruk, kemudian berubah statusnya menjadi berstatus gizi baik. Sementara 2 balita lainnya masih tetap dalam status gizi kurang/buruk.

Evaluasi berdasarkan hasil penimbangan masih menunjukkan hasil yang kurang maksimal. Hanya 5 dari 7 balita yang status gizinya bisa berubah menjadi lebih baik. Berdasarkan hasil evaluasi, secara pengetahuan dan kemauan untuk berubah sudah ditunjukkan oleh pengasuh ke arah yang lebih baik. Hanya saja perbaikan status gizi juga dipengaruhi oleh faktor lain yang lebih dominan, kemiskinan (Zhao \& Yu, 2019)(Chaturvedi, 2019)(Lone, Lone, \& Mayer, 2019).

\section{Mencermati Proses Pendampingan}

Pendampingan merupakan sebuah proses membersamai sasaran. Pendampingan lebih menekankan untuk bersama-sama berproses untuk mencapai suatu tujuan. Pada tahap awal pendampingan, perlu dibangun keeratan hubungan dengan masyarakat sasaran. Ikatan hubungan yang baik (raport) harus diupayakan sebelum jauh melangkah pada substansi pendampingan. (Jerez Yàñez, Aranda Càceres, Corvalán Canessa, González Rojas, \& Ramos Torres, 2019)(Le Galès \&

Ikatan hubungan yang baik (raport) harus diupayakan sebelum jauh melangkah pada substansi pendampingan. Bungener, 2019)(Nakache, 2019).

Hidup bersama-sama (live in) dengan masyarakat sasaran seperti yang dilakukan dalam Riset Aksi Partisipatif Desa Sehat Berdaya merupakan suatu langkah yang baik untuk membangun raport tersebut. Pada posisi ini, Sahabat Desa selaku pendamping, yang juga berperan menjadi peneliti, berkesempatan lebih intensif 
untuk membangun ikatan dengan masyarakat sasaran (Koentjaraningrat, 1993)(Spradley, 2007).

Raport yang baik akan memberi kepercayaan masyarakat sasaran pada pendamping. Pendamping tidak lagi dianggap sebagai orang asing, pendamping sudah dianggap sebagai bagian dari

Pada beberapa substansi

pendampingan yang

sensitif, misalnya aborsi dan pelacuran, diperlukan raport yang benar-benar sangat baik. Ikatan yang terbangun antara pendamping dan sasaran sudah harus benar-benar bukan "orang lain" lagi. masyarakat itu sendiri. Dengan live in, pendamping sebagai peneliti memiliki kesempatan yang luas untuk mengalami peristiwa keseharian bersama masyarakat sasaran (Laksono, Faizin, Raunsay, \& Soerachman, 2014), juga memahami permasalahan kesehatan dalam perspektif masyarakat (Megatsari, Laksono, Ridlo, Yoto, \& Azizah, 2018). Situasi ini seperti yang dialami dan diceritakan Clifford Geertz dalam catatan lapangannya tentang sabung ayam di Bali, yang dipublikasikan dengan judul "Deep play: notes on the Balinese cockfight" (Geertz, 2005). Pada awalnya Geertz dianggap asing. Tetapi situasi tersebut berbalik ketika terjadi penggerebekan di arena sabung ayam oleh polisi. Geertz ikut bubar dan berlarian bersama masyarakat lainnya. Momentum tersebut akhirnya yang mengantarkan Geertz menjadi bagian masyarakat sasarannya.

Pada beberapa substansi pendampingan yang sensitif, misalnya aborsi dan pelacuran, diperlukan raport yang benar-benar sangat baik. Ikatan yang terbangun antara pendamping dan sasaran sudah harus benar-benar bukan "orang lain" lagi (Singer, 2019)(Ladd $\&$ Neufeld Weaver, 2018). Substansi masalah status gizi buruk atau 
kurang juga merupakan hal yang cukup sensitif, karena kondisi ini bisa menjadi aib apabila diketahui oleh orang lain.

\section{Penutup}

Berdasarkan hasil penelitian dapat disimpulkan bahwa pendampingan efektif untuk menambah pengetahuan dan mengubah kemauan pengasuh balita ke arah lebih baik. Tetapi masih diperlukan upaya lain untuk lebih mengefektifkan dampak pendampingan hingga bisa berdampak lebih efektif ke perubahan status gizi yang lebih baik.

Berdasarkan hasil uraian secara umum, dapat disusun rekomendasi yang terbagi dalam dua kelompok besar, yaitu rekomendasi terkait aspek sosial budaya dan rekomendasi terkait aspek pelayanan kesehatan.

1) Aspek sosial budaya

a) Meningkatkan keeratan sosial diantara masyarakat, sehingga permasalahan kesehatan dapat dideteksi sejak dini.

b) Meningkatkan pengetahuan dan kesadaran masyarakat secara kolektif mengenai permasalahan kesehatan yang ada terutama terkait dengan gizi.

2) Aspek pelayanan kesehatan

a) Peningkatan kemampuan petugas kesehatan dalam melakukan proses pengukuran antropometri.

b) Memaksimalkan penggunaan peralatan untuk proses pengukuran antropometri.

\section{Daftar Pustaka}

Achadi, E. L. (2013). Periode Kritis 1000 Hari Pertama Kehidupan dan Dampak Jangka Panjang terhadap Kesehatan dan Fungsinya. Jakarta.

Aryastami, N. K., Shankar, A., Kusumawardani, N., Besral, B., Jahari, A. B., \& Achadi, E. (2017). Low birth weight was the most dominant predictor associated with 
stunting among children aged 12-23 months in Indonesia. BM C Nutrition, 3(1). https:// doi.org/10.1186/s40795-017-0130-x

Chaturvedi, B. K. (2019). Poverty and development: global problems from an Indian perspective. Journal of Global Ethics, 15(1), 55-66.

https://doi.org/ 10.1080/ 17449626.2019.1582557

Direktorat Gizi Masyarakat Direktorat Jenderal Kesehatan M asyarakat Kementerian

Kesehatan RI. (2018). Buku Saku Pemantauan Status Gizi 2017. Jakarta:

Kementerian Kesehatan RI.

Geertz, C. (2005). Deep play: notes on the Balinese cockfight. Research Library.

Retrieved from

https:// www.webpages.uidaho.edu/ rfrey/PDF/410/Geertz72.pdf

Gibson, R. (2005). Principles of Nutritional Assessment. Oxford: Oxford University Press.

Jerez Yàñez, Ó., Aranda Càceres, R., Corvalán Canessa, F., González Rojas, L., \& Ramos Torres, A. (2019). A teaching accompaniment and development model: possibilities and challenges for teaching and learning centers. International Journal for Academic Development, 24(2), 204-208. https://doi.org/ 10.1080/ 1360144X.2019.1594238

Koentjaraningrat. (1993). M etode Wawancara. In Koentjaraningrat (Ed.), MetodeM etode Penelitian Masyarakat (3rd ed., pp. 129-157). Jakarta: Gramedia Pustaka Utama.

Kusumawardani, N., Soerachman, R., Laksono, A. D., Indrawati, L., H., P. S., \& Paramita, A. (2015). Penelitian Kualitatif di Bidang Kesehatan. Yogyakarta: PT Kanisius.

Ladd, S. K., \& Neufeld Weaver, L. (2018). M oving forward: Collaborative accompaniment of human trafficking survivors by using trauma-informed practices. Journal of Human Trafficking, 4(3), 191-212. https:// doi.org/ 10.1080/23322705.2017.1346445

Laksono, A. D. (2015a). Anyiman: Studi Etnografi Makanan Suku Muyu (Anyiman: Ethnographic Study of Muyu Tribal Foods). (R. Soerachman, S. Sumarmi, \& T. J. Angkasawati, Eds.). Jogjakarta: PT Kanisius.

Laksono, A. D. (2015b). Pengumpulan Data Penelitian Kualitatif. In Kasnodihardjo (Ed.), Penelitian Kualitatif di Bidang Kesehatan (pp. 15-34). Jogjakarta: PT Kanisius.

Laksono, A. D., Faizin, K., Raunsay, E. M ., \& Soerachman, R. (2014). M uyu women in exile (Perempuan M uyu dalam Pengasingan). Jakarta: Lembaga Penerbitan Balitbangkes. Retrieved from https:// www.scribd.com/doc/261673624/Perempuan-Muyu-dalamPengasingan-Riset-Ethnografi-Kesehatan-2014-Boven-Digoel

Laksono, A. D., Megatsari, H., Ridlo, I. A., Yoto, M., Azizah, A. N., Jabbar, N. A., \& 
Muhammad, A. (2019). Analisis Sosiogram untuk Penentuan Agen

Perubahan; Studi Kasus pada Program Desa Sehat Berdaya. Buletin Penelitian Sistem Kesehatan, 22(1).

Le Galès, C., \& Bungener, M. (2019). The family accompaniment of persons with dementia seen through the lens of the capability approach. Dementia, 18(1), 55-79. https:// doi.org/ 10.1177/1471301216657476

Lone, B. A., Lone, S. A., \& Mayer, I. A. (2019). Socio-economic vulnerability assessment of female children to malnutrition in rural Baramulla district of Kashmir Himalayas, India. GeoJournal. https://doi.org/10.1007/s10708-01909980-6

Megatsari, H., Laksono, A. D., Ridlo, I. A., Yoto, M., \& Azizah, A. N. (2018). Community Perspective about Health Services Access. Buletin Penelitian Sistem Kesehatan, 21, 247-253. https:// doi.org/10.22435/hsr.v2li4.231

M oradi, S., M irzababaei, A., M ohammadi, H., M oosavian, S. P., Arab, A., Jannat, B., $\&$ Mirzaei, K. (2019). Food insecurity and the risk of undernutrition complications among children and adolescents: A systematic review and meta-analysis. Nutrition, 62, 52-60.

https:// doi.org/10.1016/j.nut.2018.11.029

Murlan, M., Ruwiah, R., Suardi, S., Lestari, W., \& Pratiwi, N. L. (2015). Knowledge, Attitude And Practice of M other with Children Under Five Years on The Use of Virgin Coconut Oil's Residue to Local Foods to Increase Child's Nutritional in Buton. Bulletin of Health System Research, 18(3), 257-265.

https:// doi.org/10.22435/hsr.v18i3.4547.257-265

Nakache, D. (2019). M igrant W orkers and the Right to Family Accompaniment: A Case for Family Rights in International Law and in Canada. International Migration, 56(6), 221-235. https:// doi.org/10.1111/imig.12444

National Institute of Health Research and Development of M inistry of Health of the Republic of Indonesia. (2019). The 2018 Indonesia Basic Health Survey (Riskesdas): National Report. Jakarta.

Nyati, L. H., Pettifor, J. M ., \& Norris, S. A. (2019). The prevalence of malnutrition and growth percentiles for urban South African children. BM CPublic Health, 19(1). https://doi.org/10.1186/s12889-019-6794-1

Pemerintah Desa Arjosari. (2017). Profil Desa Arjosari 2017. Pasuruan.

Pramono, M. S., \& Paramita, A. (2015). Pattern of Occurrence and Determinants of Baby with Low Birth Weight in Indonesia 2013. Bulletin of Health System Research, 18(1), 1-10. https:// doi.org/10.22435/hsr.v18i1.4263.1-10

Pusat Data dan Informasi Kementerian Kesehatan RI. (2015). Situasi Kesehatan Anak Balita di Indonesia. Jakarta: Kementerian Kesehatan RI.

Pusat Data dan Informasi Kementerian Kesehatan RI. (2017). Profil Kesehatan Indonesia Tahun 2016. Jakarta: Kementerian Kesehatan RI. 
Singer, E. O. (2019). Realizing Abortion Rights at the Margins of Legality in M exico. M edical Anthropology: Cross Cultural Studies in Health and IIIness, 38(2), 167-181. https:// doi.org/10.1080/01459740.2018.1474213

Spradley, J. P. (2007). M etode Etnografi (second edi). Tiara Wacana.

Sumarmi, S. (2017). TINJAUAN KRITIS INTERVENSI M ULTI M IKRONUTRIEN

PADA1000 HARI PERTAMA KEHIDUPAN. Penelitian GizidanM akanan, 40(1), 17-28. https:// doi.org/10.22435/pgm.v40i1.6374

World Bank. (2010). Scaling Up Nutrition; A Framework for Action. World Bank.

World Health Organization. (2009). WHO AnthroPlus for Personal Computers, Manual Software for assessing growth of the world's children and adolescents. Geneva: World Health Organization.

Wulansari, S., Sadewo, F. S. \& Raflizal, R. (2015). Social Construction and Action of Mother of M alnutrition Toddler (A Case Study in Sampang and Bojonegoro). Bulletin of Health System Research, 18(1), 65-75. https://doi.org/10.22435/hsr.v18i1.4272.65-75

Zhao, Q., \& Yu, X. (2019). Parental Nutrition Knowledge, Iron Deficiency, and Child Anaemia in Rural China. Journal of Development Studies.

https://doi.org/ 10.1080/00220388.2019.1573315 